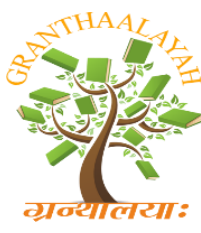

INTERNATIONAL JOURNAL OF RESEARCH GRANTHAALAYAH A knowledge Repository

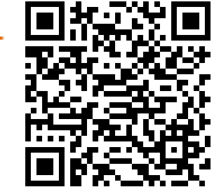

\title{
ENVIRONMENTAL IMPACT OF IDOL IMMERSION ON KAKERPURA LAKE MHOW
}

\author{
D.K. Billore ${ }^{1}$, Maneesha Dandawate ${ }^{2}$ \\ ${ }^{1}$ Department of Botany. G.P.G. College, Mundi \\ ${ }^{2}$ Department of Botany G.P.G. College, Mhow
}

\begin{abstract}
This paper intends to prepare the environmental impact of "Ganesh Idol" \& "Durga Pratima" immersion on water quality of Kakerpura Lake, Mhow. For this purpose site of Kakerpura lake was selected where idols are actually immersed. Water samples were collected in morning at different intervals i.e. pre-immersion (August) immersion (September, October) Post immersion period (November). The "Ganesh Idols" \& "Durga Pratima" are made up of degradable and nondegradable components and paints containing heavy metals due to that immersion activity deteriorates water quality. The physico-chemical parameters were analysed to study the environmental impact of idol immersion on Kakerpura Lake and these parameters shows the significant variation due to immersion of idols.
\end{abstract}

Keywords:

Pollution, idol immersion, kakerpura lake, water quality.

\section{INTRODUCTION}

All forms of life depend upon water \& it provides sustenance of plants, animals, aquatic organisms to meet the human need like agriculture and industries (Prasad \& Gaur 1992). The quantity \& quality of utilizable water is degrades due to overexploitation and increase of pollution by the dumping of domestic, industrial and hospital waste, domestic activities like washing, bathing and religious rituals (Shukla 2004 and Gupta et al 2011). India is the country of rituals and people believed in these and they deeply follow it. Most of the rituals are performed near banks of river of water bodies. The "Ganesh Chaturthi" is one of the important festival of Hindi and during this festivals thousands of Ganesh idols of various sizes are immersed every year in different water bodies. Similarly in Kakerpura Lake about 600-700 Ganesh Idols \& 400-500 Durga Pratima are immersed. Idols are constructed by plaster of paris, clay, cloths, small iron rod, bamboo and decorated with different paints such as varnish, water colour, when these idols are immersed in water bodies, these constituting components lead to significant alteration in water quality (Photel et al 2001; Reddy \& Kumar 2001, Bajpai et al 2002, Mukherjee 2003, Swain et al 2005; Vyas et al; 2006, 2008, Vyas and Bajpai 2008; Vyas and Bajpai 2008, Dhote \& Dixit 2011 and Bhat et al 2012 ). The input of Biodegradable and non-biodegradable substances deteriorates the water quality and enhances silt load in the river. The floating material released through idol in the river and lake after decomposition result in eutrophication (Leland, 1991). 


\section{MATERIALS \& METHOD}

For this study water samples were collected from surface water during morning hours, from actual immersion site.

During the Ganesh festival 2012 at different intervals i.e. Pre-immersion (Aug) immersion of Ganesh idol (Sep.), Durga Pratima visarjan (Oct.) Post immersion (Nov.) period samples were collected and were subjected to analyze physico-chemical parameters including $\mathrm{pH}$, temperature, Transparency, total Hardness, dissolved oxygen (DO), calcium, BOD, Total alkalinity and oil \& Grease to follow the standard methods of Trivedi \& Goyal (1980) and APHA (2005). The measurement of temp and $\mathrm{pH}$ of water samples conducted at Lake Site while for analysis of other parameter the samples are collected in well rinsed and pre cleaned plastic canes and transferred to research lab.

\section{RESULTS \& DISCUSSION}

The environmental impact of Ganesh idol immersion activity \& Durga Pratima visarjan on water quality of Kakerpura Lake assessed and significant changes in physico-chemical properties of water were observed.

The $\mathrm{pH}$ of water is important because it affects solubility of nutrients. $\mathrm{pH}$ was determined by the digital $\mathrm{pH}$ meter and significant variation was observed during the study. It was noted acidic or high $7.6-7.8$ during the immersion period while it was low 6.9 to 7.1 during the pre-immersion and post immersion period respectively. (Table - 1)

The temperature of water was measured and there were changes in temperature were observed. The temperature which is observed in pre-immersion period was $27.5^{\circ} \mathrm{C}$ while post immersion $25^{\circ} \mathrm{C} \&$ during immersion period it was from 28.0 -32 respectively (Table-1) Rising in temperature directly affect $\&$ speed up the chemical reaction $\&$ biological activity that reduces the solubility of gases in water (Murugesan et $\underline{\text { al }}$, 2004).

Sacchi disc transparency varied between pre-immersion, immersion \& Post immersion period. The minimum transparency observed in month of August because increased amount of particles were added due to surface run-off. (Rainy season). It was observed between $25-27 \mathrm{~cm}$ in immersion period due to total dissolved solid particles and in post immersion period it was as high as $33 \mathrm{~cm}$. Dissolved $\mathrm{O}_{2}$ (DO) having great importance in water quality monitoring and it considered an important factor which reflects physical \& biological processes in water body. Dissolved oxygen is one of the important parameter for the assessment of the solubility of water for flora \& Fauna. During immersion period dissolved $\mathrm{O}_{2}$ was observed very low from 4.4 to $4.0 \mathrm{mg} / \mathrm{L}$ while during pre-immersion period it was $5.8 \mathrm{mg} / \mathrm{L}$ while $6.8 \mathrm{mg} / \mathrm{L}$ in post immersion period. The idol immersion adversely affects the dissolved oxygen in water body and during this investigation it is observed in Kakerpura lake decrease in (DO) was due to cumulative effect of various religions activities and rise in temperature. Total hardness in not a pollution indicator but it indicates water quality. In this study high value $160 \mathrm{mg} / \mathrm{L}$ to $170 \mathrm{mg} / \mathrm{L}$ was observed during immersion period while low $115 \mathrm{mg} / \mathrm{L}$ was observed in pre immersion \& $145 \mathrm{mg} / \mathrm{L}$ observed in post immersion period. Materials used for the preparation of idols is responsible for increasing hardness and in present study high value of total hardness was observed during the immersion activity. Total alkalinity is the buffering capacity of water and it increased due to various religious activities and domestic waste. In present study it was found high 310-340 mg/L during immersion period compared to pre immersion $290 \mathrm{mg} / \mathrm{L}$ and Post immersion $230 \mathrm{mg} / \mathrm{L}$ period respectively. Increase in value of total alkalinity was related to carbonate \& bicarbonate concentration and the total alkalinity value were fluctuated due to idol immersion (waikol and patil 2009). Biological oxygen 
demand (BOD) is one of the pollution indicating parameter and it increases due to decomposition of organic matter. BOD was observed quite high $5.4-6.0 \mathrm{mg} / \mathrm{L}$ during immersion period that was significantly high compare to pre-immersion 4.8/L and post immersion period 4.0 (Table-1). The high values of BOD has direct correlation with the increase in nutrient level of the lake due to immersion activity (McCoy \& olson 1986). Oil \& grease was observed high 0.6 to $0.8 \mathrm{mg} / \mathrm{L}$ during immersion period while pre-immersion \& post immersion period it found low .33 to $.60 \mathrm{mg} / \mathrm{L}$ respectively (Table- I) During immersion period the oil \& grease was increased due to oil paint used for decoration of the idol and devotee offer oil to the Lord Ganesha \& Durga ji during the worship. In present study total calcium was analysed and result were depicted in table- I. The total calcium observed high 25.5 to $26.5 \mathrm{mg} / \mathrm{L}$ during immersion period \& low $15.50-20.5 \mathrm{mg} / \mathrm{L}$ during pre-immersion \& Post-immersion period. Reddy and Kumar (2001) observed that the concentration of calcium had increased significantly in the lake water after the idol immersion in the Hussain Sagar Lake Andhra Pradesh.

\section{CONCLUSION}

Mythologically the water bodies are related to religious sentiments but scientifically these are not suitable for human uses. The main reason of the deterioration in water quality is various ritual activities in that "Idol immersion" plays an important role because these idols are made by plaster of paris \& clothes, small iron rods, chemical colours, varnish and paints used as decorative components. These religious activity cannot stop but awareness among people and proper management practices like use of eco-friendly Ganesh idols \& Durga Pratima natural colors etc. can reduce the pollution problem of water bodies up to some extent.

\section{REFERENCES}

1. APHA (2005). Standard methods for examination of water and waste water. American Public Health Association, Washington, DC.

2. Azahar and Multani A (2011). Impact of Ganesh Idol Immersion on Tapi River at Ashwanikumar Ovara. M.Sc. Dissertation Veer Narmad South Gujarat University Surat.

3. Bajpai A, Pani S, Jain RK and Mishra SM (2002). Heavy metal contamination through idol immersion in a tropical lake. Eco: Environment and Conservation organization 8(2) 157159.

4. Bhat Najeeb A, Wanganeo Rajni and Wanganeo Ashwani (2012). Pollution Status of Bhoj Wetland before and after Immersion of Idols. South Asian Journal Tourism and Heritage 5(1) 153-156.

5. Dhamijia SK and Jain Y (1995). Studies on the water quality index of a lentic waterbody at Jabalpur Madhya Pradesh. Polling and Research Consultancy 14(3) 341-346. International Journal of Geology, Earth and Environmental Sciences ISSN: 2277-2081 (Online) An Online International Journal Available at http://www.cibtech.org/jgee.htm 2012 Vol. 2 (3) September - December, pp.11-16/Ujjania and Mistry Research Article 16

6. Dhote Sangeeta and Dixit Savita (2011). Hydro chemical changes in two eutrophic lakes of Central India after immersion of Durga and Ganesh idol. Research Journal of Chemical Sciences 1(1) 38-45.

7. Dhote $S$, Varghese B and Mishra SM (2001). Impact of idol immersion on water quality of twin lakes of Bhopal. Indian Journal of Environment Protection 21 998-1005. 
8. Gupta Anil Kumar, Mishra Kavita, Pramod Kumar, Singh Chandrasekhar and Srivastava Sumita (2011). Impact of religious activities on the water characteristics of prominent ponds at Varanasi (U.P.) India. Plant Archives 11(1) 297-300.

9. Leland $H V$ (1991). Transport and distribution of trace elements in a watershed ecosystem in environment. Edited by W. R. Boggess and B.G.Wixsion (Castle House Publication Van Nuyas CA) 105-134.

10. Malik GM, Raval VH, Zadafiya SK and Patel AV (2012). Idol immersion and PhysicoChemical properties of South Gujarat Rivers India. Research Journal of Chemical Sciences 2(3) 21-25.

11. McCoy WF and Olson BH (1986). Relationship among turbidity particle counts and bacteriological quantity with in water distribution lines. Water Research (20) 1023.

12. Mukerjee A (2003). Religious Activities and Management of Water Bodies - Case Study of Idol Immersion in Context of Urban lakes Management. International Water Histroy Association (3) 325.

13. Prasad D and Gaur HS (1992). Environmental pollution: Water, Venus Publishing House, New Delhi 294-330.

14. Reddy Vikram M and Kumar Vijay A (2001). Effects of Ganesh Idol Immersion on some water quality parameter of Hussainsagar. Current Science 81 1412. Shukla SS (2004). Effect of Public Awareness Campaign in Mitigating impact of religious activities on Bhopal Lakes. Global Biodiversity Forum (2) 17.

15. Swain SK, Mohapatra S and Patel RK (2005). A measure of pollution load in temple ponds of Puri Orissa on the basis of NSF-WQI suggestions. Polling and Research consultancy 24(3) 599-603.

16. Trivedy PK and Goel RK(1986). Chemical and Biological methods water pollution studies. Environmental publication Karad India.

17. Vyas Anju and Bajapai A (2008). Water quality survey and monitoring study of idol immersion in context of lower Lake Bhopal India. In: Proceedings of tall 2007: the 12th World Lake congress edited by Sen Gupta M and Dalwani R 1818-1823.

18. Vyas Anju, Mishra DD, Bajapai A, Dixit S and Verma N (2006). Environment Impact of Idol Immersion Activity Lakes of Bhopal India. Asian Journal of Experimental Sciences 20(2) 289. 